\title{
Clinical cell-based cardiac regeneration therapy in patients with ischemic heart failure
}

\author{
Mariann Gyöngyösi', Noemi Nyolczas², Claudia Müller ${ }^{1}$, Katrin Zlabinger ${ }^{1}$, \\ Ljubica Mandic', Martin Riesenhuber ${ }^{1}$, Paul Haller ${ }^{1}$, Sandor Batkai', \\ Denise Traxler ${ }^{1}$
}

\author{
${ }^{1}$ Dept. Cardiology, Medical University of Vienna, Austria \\ ${ }^{2}$ Dept. of Cardiology, Medical Centre Hungarian Defence Forces, Hungary \\ ${ }^{3}$ Cardior Pharmaceuticals GmbH, Hannover, Germany \\ Corresponding author: \\ Mariann Gyöngyösi MD, Dept. Cardiology, Medical University of Vienna, Austria, Email: mariann.gyongyosi@meduniwien.ac.at
}

\begin{abstract}
Since the number of the autologous remnant cardiac progenitor cells and the mobilized cells form the bone marrow upon injury signal are too low, as well as the own myocyte proliferation rate is insufficient for complete recovery of the heart after ischemic injury, external regenerative cells are implanted into the injured heart to promote the regeneration process. Accordingly, the clinical cardiac regeneration treatment with the intention to improve clinical symptoms, quality of life, and LV performance, as well as prevention of hospitalization, reduction of mortality and morbidity came into the forefront of pre-clinical and clinical investigations in the last 15 years. The majority of the heart failure clinical cell-based cardiac regeneration studies included patients with low ejection fraction $(<40 \%)$, and applied the cells (mostly bone-marrow, or mesenchymal stem cells) percutaneously intramyocardially. Most studies and meta-analyses resulted in moderate improvement of the left ventricular function and quality of life, however, the last three randomized trials failed to reach the primary efficacy endpoints. To enhance the effectiveness of the regeneration therapy in heart failure, cell-free therapy with paracrine factors, including exosomes and cell function modulators, such as noncoding RNAs came into foreground.
\end{abstract}

Keywords: heart failure, cell-based cardiac regeneration therapy, cell-free therapy, clinical studies

Klinikai sejtalapú kardiális regenerációs kezelés az iszkémiás szívelégtelenségben szenvedö betegekben Ismert, hogy az autológ kardiális progenitor sejtek és a myocadium sérülés hatására a csontvelőből mobilizált sejtek száma túl alacsony és a cardiomyocyták saját proliferációs képessége nem elegendő a szív iszkémiás károsodásának teljes regenerálásához. Teoretikusan, reparatíve sejtek sérült myocardiumba való implantálása elösegítheti a regeneráció folyamatát. Ennek megfelelően az elmúlt 15 évben a klinikai tünetek, az életminőség és a balkamra-funkció javítását, a hospitalizáció megelőzését és a mortalitás valamint a morbiditás csökkentését célzó kardiális regenerációs kezelés a preklinikai és klinikai vizsgálatok élvonalába került. A szívelégtelenségben végzett sejtalapú, klinikai, kardiális regenerációs vizsgálatok többségében alacsony bal kamra ejekciós frakciójú (LVEF<40\%) betegek kerültek besorolásra és az alkalmazott sejtek elsősorban csontvelői eredetű, vagy mesechymalis őssejtek voltak, amelyeket percutan intramyocardialisan alkalmaztak. A legtöbb vizsgálat és metaanalízis a balkamra-funkció és az életminőség mérsékelt javulását mutatta, a legutóbbi három randomizált vizsgálat azonban nem igazolt kedvező változást a primer effektivitási végpontokat illetően. Szívelégtelenségben a regenerációs terápia hatásosságának javítása céljából a sejtmentes kezelési alternatívák, így parakrin faktorok többek között exosomák, sejtfunkció-modulátorok pl. nem kódoló RNS-ek alkalmazása került előtérbe.

Kulcsszavak: szívelégtelenség, sejtalapú kardiális regenerációs kezelés, sejt-mentes regenerációs terápia, klinikai vizsgálat 


\section{Introduction}

The incidence of ischemic heart failure (HF) caused by coronary artery disease (CAD) is increasing due to successful reduction of acute complications of myocardial infarction and improved survival. Those patients are typically left with reduced left ventricular (LV) with subsequent chronic heart failure symptoms. The available therapeutic options are limited to medical treatment to improve their symptoms, apart from device therapy/ heart transplantation in serious cases. Since the number of the autologous remnant cardiac progenitor cells and the mobilized cells form the bone marrow upon injury signal are too low, as well as the own myocyte proliferation rate is insufficient for complete recovery of the heart after ischemic injury, external regenerative cells are implanted into the injured heart to promote the regeneration process. Accordingly, the cardiac regeneration treatment with the intention to improve clinical symptoms, quality of life, and LV performance, as well as prevention of hospitalization, reduction of mortality and morbidity came into the forefront of pre-clinical and clinical investigations in the last 15 years.

\section{Cells used for cardiac regeneration in ischemic HF}

At the beginning of the cell-based regenerative therapy, unselected mixed cells of bone marrow origin were used in clinical trials for cardiac repair, because of a lack of information about which cell type would be best suited. Most bone marrow cells belong to hematopoietic and lymphatic lineage and produce mature blood cells. Other bone marrow cell types are also present, which, however, are undesirable in the areas of myocardial injury, such as osteoblasts, pericytes, and pre-adipocytes. In fact, in these mixed cell populations only a small proportion (approx. 1\%) of bone marrow cells are progenitors or stem cells suitable for cardiac regeneration purposes (1). Among them, hematopoietic and mesenchymal stromal cells (MSCs), other mononuclear cells, CD34+ cells, CD133+ cells home in the bone marrow. However, unselected bone marrow cells did not substantiate breakthrough regenerative effect in clinical scenario.

Mesenchymal stromal cells (MSCs) are multipotent stem cells, and apart from bone marrow, they can be found in several organs indicating their importance in tissue regeneration in general. Pre-clinical studies reported their reparative capacity uniquely, regardless of their origin. MScs are immune privileged, less recognized by the host immune system and have immunosuppressive characters; for those reasons, they are preferred for allogeneic cell therapy. MSCs are known to secrete hundreds of proteins, such as growth factors (VEGF, HGF, IGF-1), anti-apoptotic and anti-inflam- matory mediators, SFRP-2, angiogenin, cystatin, all of them are essential in cardiac regeneration $(2,3)$.

The broad use of unselected or selected bone marrow cells is limited by several factors, such as the extensive cell culture conditions and the several passages that are necessary to reach the required number of selected cells, as well as their usual autologous origin (sick cells from sick patients), or the narrow time window between harvesting and clinical application. In order to overcome the disadvantages of bone marrow derived MSCs, the use of adipose tissue-derived mesenchymal or stromal cells (ADSCs) were also explored in subsequent clinical trials. The usual source of the ADSCs is the abdominal adipose tissue, gained by liposuction. The ultimate advantage of ADSCs is the possibility to be produced under sterile GMP conditions, as ATMP (Advanced Therapy Medicinal Product), a "regenerative substance", ready to use with long shelf life (commercial off-the-shelf product). Furthermore, ASCs grow faster than MSCs during culture expansion.

Other potential sources of cardiomyogenic cells that exhibit MSC properties have also been identified. Those includes endometrial regenerative cells, mesenchymal cells derived from menstrual blood, and those derived from endometrium. These cells typically express surface markers such as CD29 and CD105, suggesting MSC properties and they can exert cardiomyocyte-like action potentials.

The discovery of the cardiac stem cells (CSCs) and cardiosphere-derived cells (CDCs) (4) that are positive for self-renewing c-kit and clonogenic, opened up new directions in cardiac regenerative therapy and two phase I trials were initiated using those cells. The SCIPIO (5) and the CADUCEUS (6) trials were designed to investigate the effect of CSCs and CDCs in patients with subacute myocardial infarction and ischemic HF, resepectively. The SCIPIO trial demonstrated that intracoronary infusion of autologous CSCs led to better left ventricular ejection fraction in a small subset of patients (5) but CADUCEUS showed no effects on the primary endpoint (systolic function), although scar dynamics and the ability of the regenerative muscle to distend did improve (6).

Beside searching of new therapeutic cell types, further cell processing methods were developed to enhance the homing, vascularizing and muscle regenerative capacity of the injected cells. The Ixmyelocel-T composite is an expanded bone marrow mononuclear cell mixture, with about 200x higher number of M2 macrophages (anti-inflammatory cells) and 50x higher number of CD90+ BM-MSCs (regenerative cells). The Ixmyelocel-T Phase $2 \mathrm{~b}$ randomized study was a part of the ixCELL-DCM trial, and included patients with ischemic dilated cardiomyopathy with an ejection fraction $\leq 35 \%$. The percutaneous transendocardial delivery of Ixmyelocel-T led to significant reduction of clinical cardiac adverse events, without affecting the ejection fraction (7). The C-Cure cells were autologous bone-marrow origin 

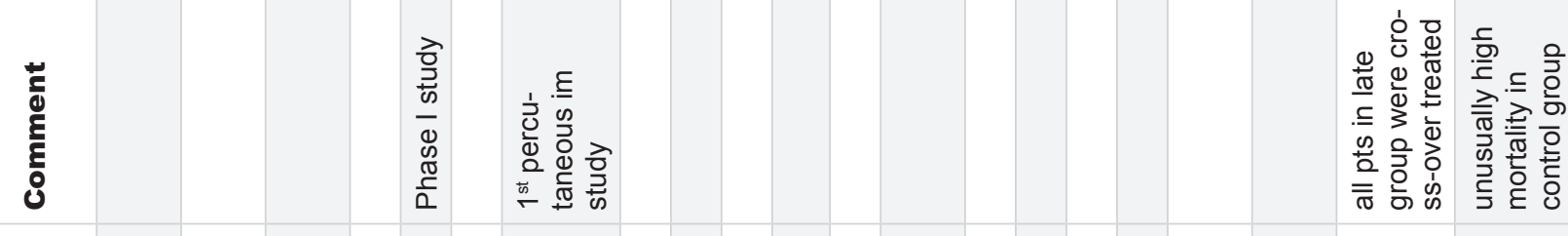

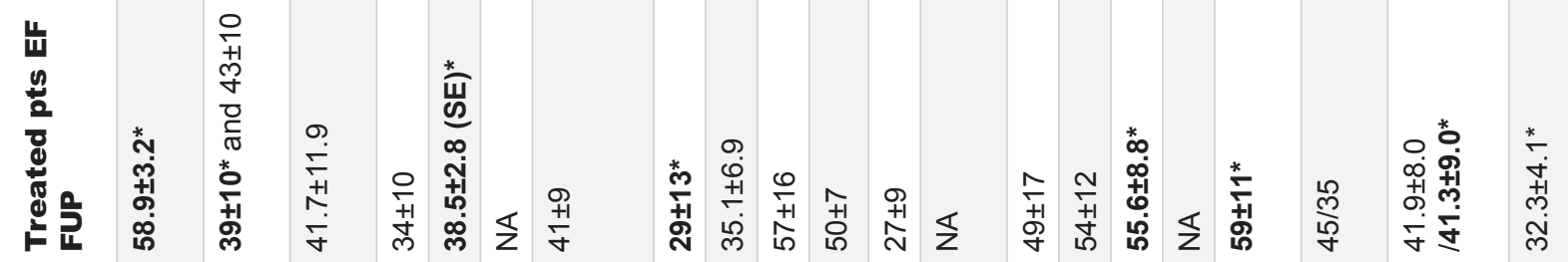

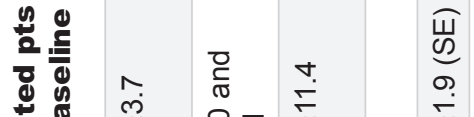

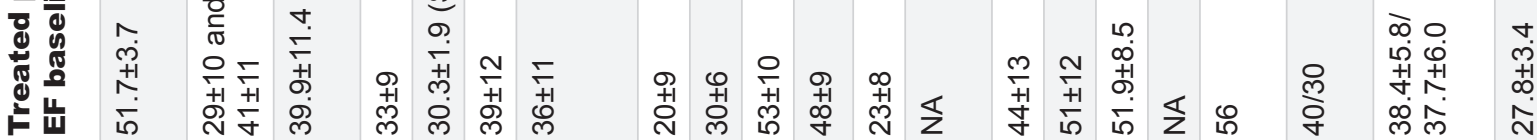

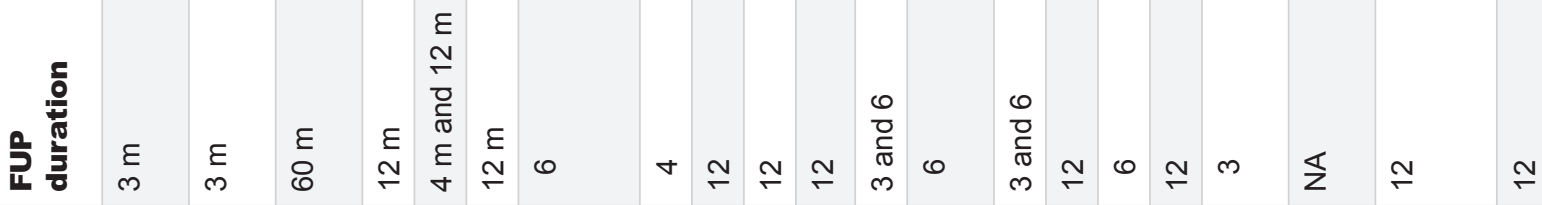

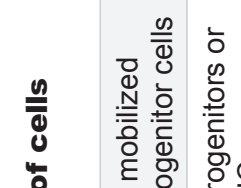

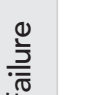

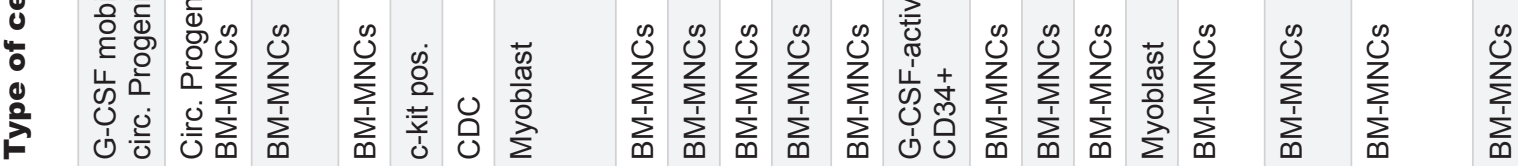

$\div \frac{0}{0}$

\section{(1)}

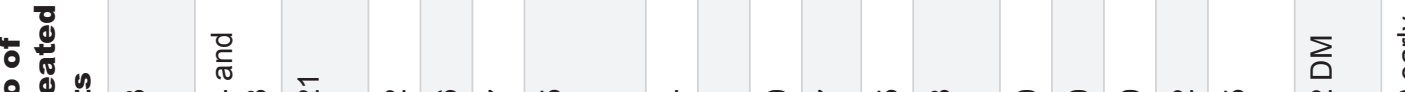

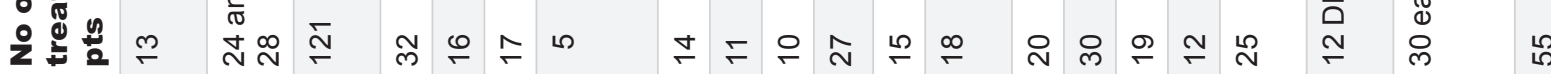

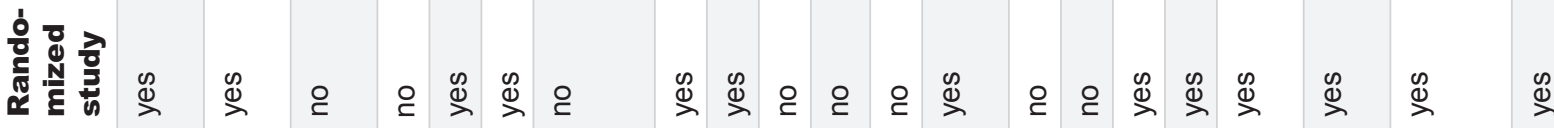

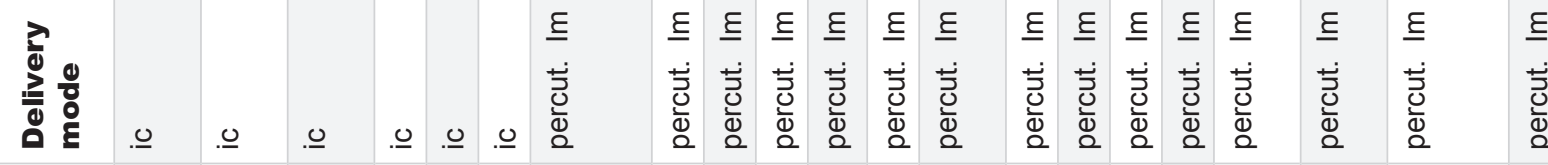

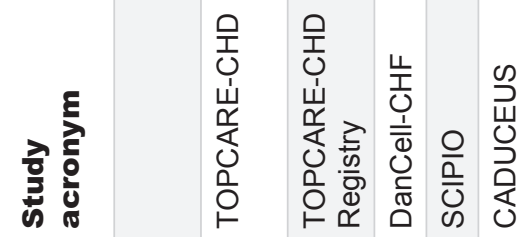

원

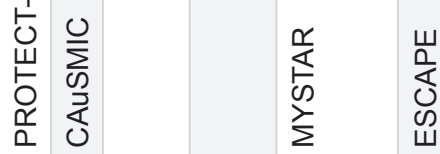

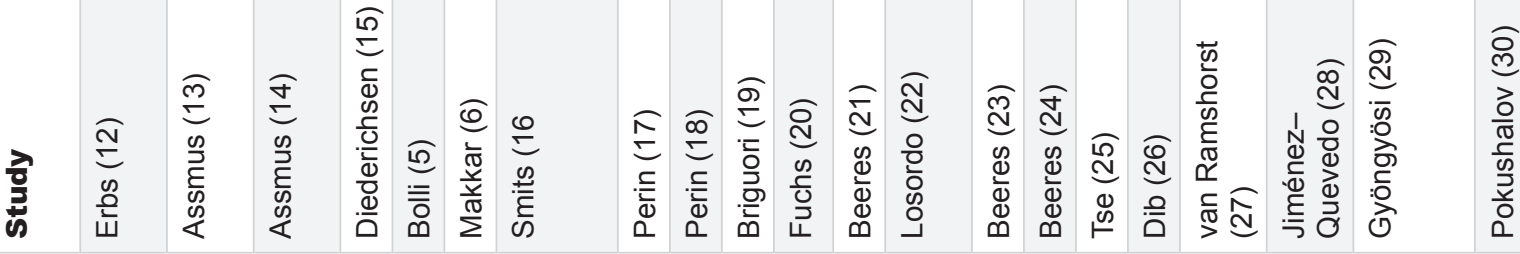




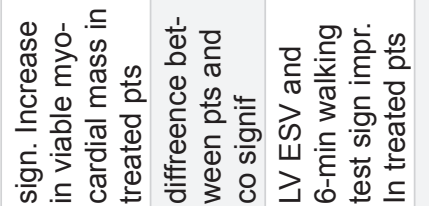

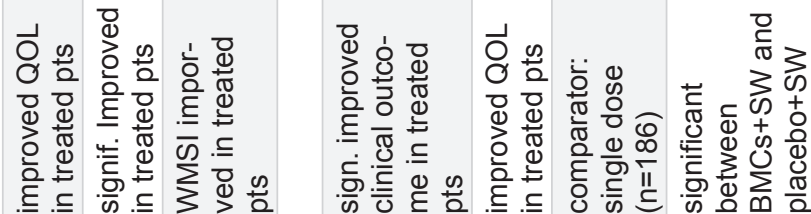

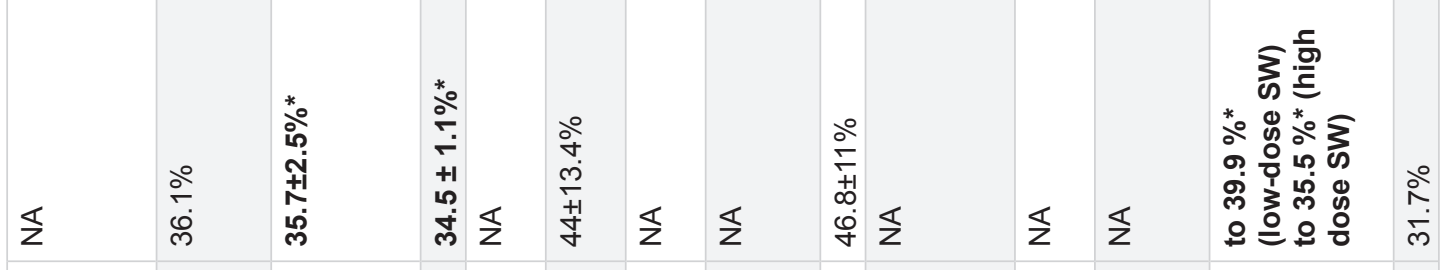

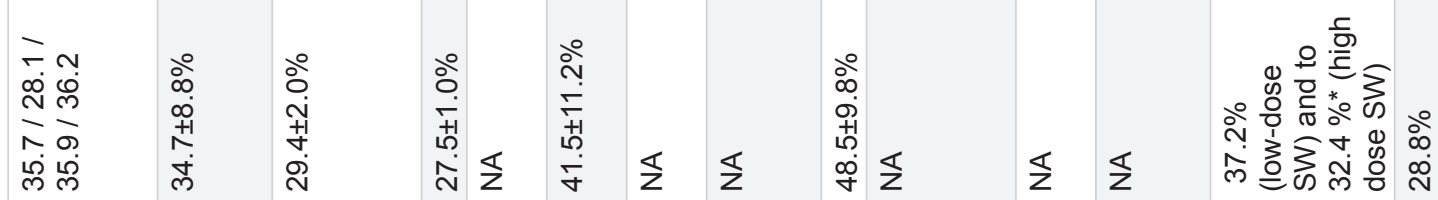

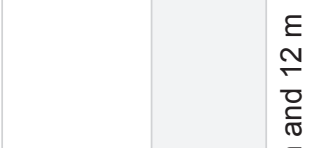

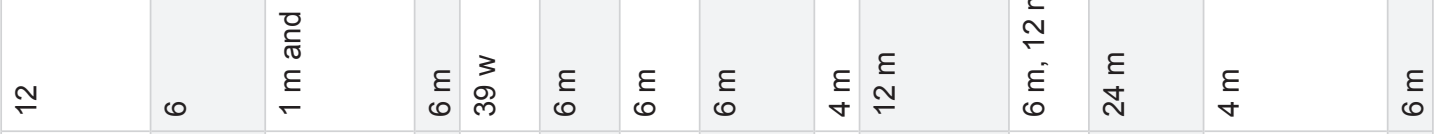

\begin{tabular}{l}
$\frac{8}{80}$ \\
$\frac{0}{0}$ \\
$\frac{0}{2}$ \\
\hline \\
$\sum_{0}^{\infty}$ \\
$\sum_{0}^{\infty}$
\end{tabular}

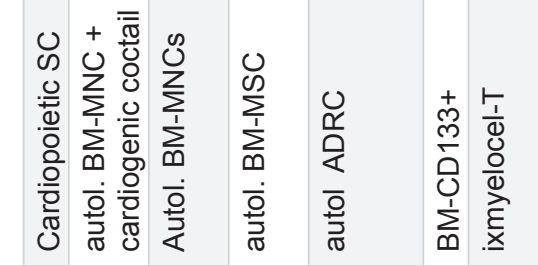

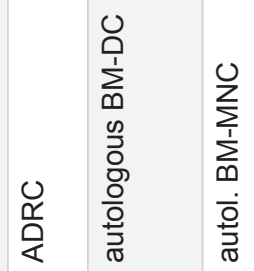

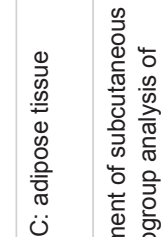

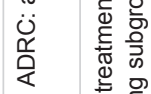

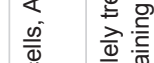

(n)

우

产

$\sum_{i=1}^{\infty} \sum_{0}^{\infty}$

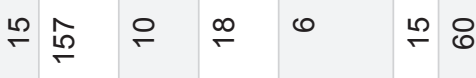

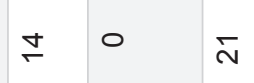

高

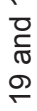

๓ 0

18

$\vDash \quad \Sigma \quad \infty$

0
0
0
$\frac{1}{0}$
0
$\frac{0}{\sigma}$

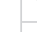

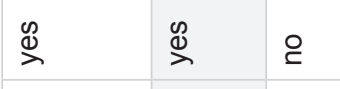

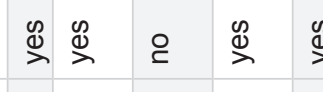

छ $\underline{\xi} \underline{\xi}$

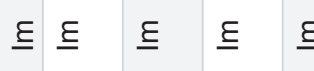

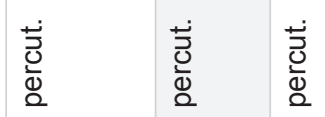

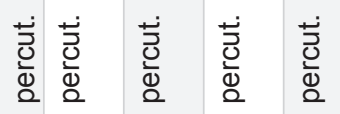

$\stackrel{\infty}{\stackrel{0}{\infty}}$

$\stackrel{\infty}{\supset} \stackrel{\infty}{\varnothing}$

$\underline{\underline{\varepsilon}}$

苞苛

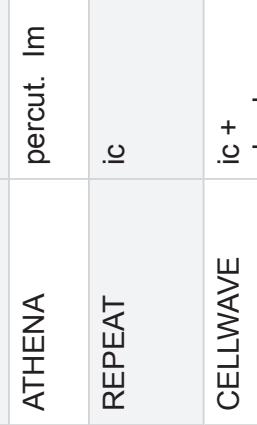

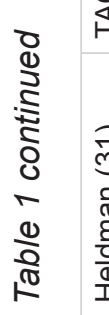

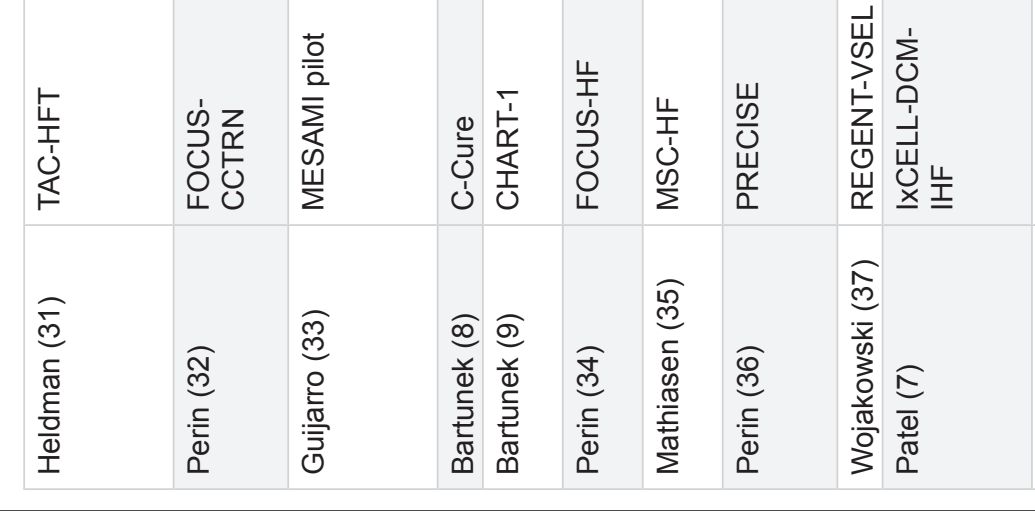

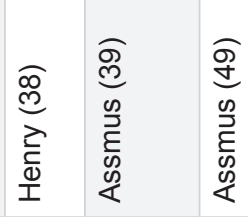

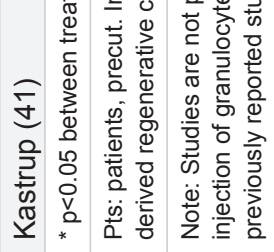


MSCs, subjected to a cardiogenic cocktail to trigger the expression and nuclear translocation of cardiac transcription factors in order to achieve lineage specification and maintaining clonal proliferation (8). After 3 passages, only cells with $>2$-fold induction of nuclear MEF2c were selected for the clinical administration (8). Cell therapy with the $\mathrm{C}$-Cure cells led to a significant improvement in ejection fraction in a small cohort, while the larger randomized CHART-1 trial could not confirm those early results (9).

\section{Application mode of cell therapy in HF patients}

The various mode of applications, the advantages and disadvantages of the percutaneous intracoronary, intramyocardial and surgical direct intramyocardial delivery of cells or other regenerative substances have been previously summarized (10). Briefly, percutaneous intracoronary cell delivery represents the easiest way to transplant cells into the heart via the coronary arteries, allowing unlimited amounts of cells or injection volume, albeit with rapid wash-out and less efficient biodistribution, with consequently less homing of the cells. Percutaneous intramyocardial injection of cells leads to more exact spatial cell transplantation to the ischemic area, with less washout; however, the amount of the injectable cells is limited, and the procedure is more complicated and costly (11). Surgical direct intramyocadial injection allows direct delivery and the visualization of the cell transplantation into the heart, however, it requires open heart surgery and randomization and blinding in such clinical trials is difficult. Nevertheless, patients with ischemic HF have often multiple coronary lesions, previous myocardial infarction, or bypass surgery, or occluded vessels. For that reason, the direct intramyocardial delivery mode of therapeutic cells is presumably more appropriate as the intracoronary delivery method.

\section{Clinical studies}

Up to now, more than two hundred small or medium-large cell-based cardiac regeneration studies are registered in clinicaltrials.gov home page, involving patients with ischemic HF. Several of them have not even started yet, or prematurely stopped due to lack of sponsor or slow recruiting rate.

Table 1 lists the completed and published clinical cellbased therapy studies including patients with chronic ischemic HF (5-9, 12-41). Few studies with either intravenous or surgical intramyocardial delivery modes were not included, due to small number of such studies and patients. The Table 1 shows the delivery mode, study design (randomized or not), the number of the treated and control patients, and the baseline and fol- low-up ejection fraction of the treated patients, in case these values were published.

Majority of the studies includes patients with low ejection fraction (<40\%). Eight of the 35 listed studies (22.9\%) includes 516 of 1962 patients (26.3\%) used the intracoronary delivery mode, while the others used the percutaneous intramyocardial cell transplantation.

Four intracoronary cell trials ( 3 of them from the Frankfurt group) demonstrated significant improvement of the left ventricular function in patients with ischemic HF treated with cells. From the 10 randomized intramyocardial cell therapy studies, where baseline and follow-up LV EF were reported, 8 trials showed significantly better LV EF in the cell-therapy group as compared to the controls. However, the last 3 largest randomized trials (Ixmyelocel-T Phase 2b, CHART-1 and ATHENA) could not demonstrate significantly improved LV performance after cell therapy compared to controls, albeit significantly less clinical adverse event were observed in the Ixmyelocel-T trial and the quality of life was improved in the ATHENA study in patients receiving cell treatment $(7,9,38)$.

\section{Meta-analyses}

To overcome the major obstacles of cardiac cell therapy trials, namely small size with slow patient recruitment in a relevant time frame, meta-analyses of the published data have been performed to reach the required statistical power. From the pooled data, the average EF increase with cell therapy has been found to be from $-0.16 \%$ to $5.4 \%$ with variability across studies in population size, design, and method of EF evaluation (42, 43). In all, little to moderate therapeutic benefit from cell therapy has been reported in terms of survival or cardiovascular-related adverse events, but the largest meta-analyses were able to identify persistent improvement in other clinical endpoints and LV function (Fisher 2015) (43).

The major drawback of these meta-analyses is the high heterogeneity between included trials, and that they possibly exclude relevant studies reporting median values with non-normally distributed data. The gold standard type of meta-analysis is based on the individual patient data (IPD), the consistent use of unique definitions and the transparency of data sets, and can analyze subgroups for features that may be in association with cell therapy effectiveness.

The initial IPD meta-analysis was ACCRUE (Meta-Analysis of Cell-based CaRdiac studies), which published 12 randomized studies of intracoronary cell administration in patients with recent AMI showed no effect of cell therapy on LVEF or clinical outcomes, and found no predictors or patient characteristics associated with the benefit of intracoronary cell therapy $(45,46)$. The IPD meta-analysis of trials involving patients with ischemic $\mathrm{HF}$ is currently ongoing. 
TABLE 2. Role of non-coding RNAs in cardiovascular diseases. Modified from Greco et al. (49)

\begin{tabular}{|l|l|l|}
\hline Disease & Modulation & non-coding RNAs \\
\hline $\begin{array}{l}\text { Coronary ar- } \\
\text { tery disease }\end{array}$ & Upregulated & $\begin{array}{l}\text { miR-135, miR-337-5p, } \\
\text { miR-433, miR-485-3p }\end{array}$ \\
\hline $\begin{array}{l}\text { Unstable } \\
\text { angina }\end{array}$ & Uownregulated & $\begin{array}{l}\text { miR-17, miR-92a, miR-126, } \\
\text { miR-145, miR-147, miR-155 }\end{array}$ \\
\hline $\begin{array}{l}\text { Myocardial } \\
\text { infarction }\end{array}$ & Upregulated & $\begin{array}{l}\text { miR-21, miR-25, miR-92a, } \\
\text { miR-106b, miR-126, } \\
\text { miR-134, miR-198, miR-370, } \\
\text { miR-451, miR-590 }\end{array}$ \\
\hline miR-1, miR-133, miR-208a, \\
miR-208b, miR-328, miR-499, \\
aHIF
\end{tabular}

\section{Further directions, secretomes, exosomes and non-coding RNAs}

One of the major problems with the cardiac cell therapy is the low cell retention rate, and rapid distribution of the cells in remote organs (47). In contrast, almost all clinical studies suggested some benefit of the cell therapy, either in improvement of clinical symptoms, or reduction of adverse events or increase in LV function. The reason for the benefit of the cells in light of these findings may be attributed to the secretion of paracrine-signaling factors that exert promotional effects on the myocardium and vasculature.

According to the "paracrine hypothesis", different stem cell types secrete tissue regenerative proteins and small molecules, like chemokines, cytokines, and growth factors. Several of these factors are recognized to improve cardiovascular function in acute or chronic cardiac tissue injury (48). The paracrine history paved the way to cell-free therapy approaches, e.g. cardiac regeneration without cell transplantation.

Furthermore, all cell types, also the injected stem cells secrete extracellular membrane vesicles such as exosomes and microparticles. Both of them are present naturally in all biological fluids, and store materials, including noncoding (nc)RNAs (miRNAs, IncRNAs), lipids and proteins. MicroRNAs are short, approximately 22 nucleotides long, and long noncoding RNAs are longer (>200 nucleotide), noncoding transripts that are post-transcriptional regulators of gene expressions and thus cell function. Dysfunction of ncRNAs has been associated with pathologies, including CAD and HF. Many of the ncRNAs are remarkably stable outside the cells, in the extracellular environment. The circulating non-coding RNAs are suggested to have paracri- ne mediator function in cardiac repair, involving several interacting cellular network and biological pathways to reduce cardiac inflammation, fibrosis and remodeling, and promote vascular growth and tissue regeneration, regulate survival of cells, and recruit and activate in situ stem and progenitor cell populations (Table 2) (48-50). Accordingly, a new era has evolved in the cardiac regeneration field, to replace the cells with various factors that regulate distinct pathogenic cell functions at molecular level.

In conclusion, cardiac cell therapy for patients with ischemic HF is still a promising option to reduce disease-related morbidity and mortality. In order to enhance the success of cardiac regeneration therapy, new molecular approaches using specific protein and ncRNA based factors are being assessed to achieve breakthrough in cardiac repair.

\section{References}

1. Rehman J. Bone marrow tinctures for cardiovascular disease: lost in translation. Circulation 2013; 127: 1935-7. doi: 10.1161/CIRCULATIONAHA.113.002775

2. Gnecchi $\mathrm{M}, \mathrm{He} \mathrm{H}$, Liang OD, et al., Paracrine action accounts for marked protection of ischemic heart by Akt-modified mesenchymal stem cells, Nat Med, 2005; 11: 367-368. doi: 10.1038/nm0405-367

3. Gallina C, Turinetto V, Giachino C. A New Paradigm in Cardiac Regeneration: The Mesenchymal Stem Cell Secretome. Stem cells international 2015; 2015: 765846. doi: 10.1155/2015/765846

4. Lee ST, White AJ, Matsushita S, et al. Intramyocardial injection of autologous cardiospheres or cardiosphere-derived cells preserves function and minimizes adverse ventricular remodeling in pigs with heart failure post-myocardial infarction. J Am Coll Cardiol 2011; 57: 455-65. doi: 10.1016/j.jacc.2010.07.049

5. Bolli R, Chugh AR, D'Amario D, et al. Cardiac stem cells in patients with ischaemic cardiomyopathy (SCIPIO): initial results of a randomised phase 1 trial. Lancet 2011; 378: 1847-57. doi: 10.1016/S01406736(11)61590-0

6. Makkar RR, Smith RR, Cheng K. et al. Intracoronary cardioshpere-derived cells for heart regeneration after myocardial infarction (CADUCEUS): a prospective, randomized phase I trial. Lancet 2012; 379: 895-904. doi: 10.1016/S0140-6736(12)60195-0

7. Patel AN, Henry TD, Quyyumi AA, et al, ixCELL-DCM Investigators. Ixmyelocel-T for patients with ischaemic heart failure: a prospective randomised double-blind trial. Lancet. 2016; 387: 2412-21. doi: 10.1016/S0140-6736(16)30137-4

8. Bartunek J, Behfar A, Dolatabadi D, et al. Cardiopoietic stem cell therapy in heart failure: the C-CURE (Cardiopoietic stem Cell therapy in heart failURE) multicenter randomized trial with lineage-specified biologics. J Am Coll Cardiol. 2013; 61: 2329-38. doi: 10.1016/j. jacc. 2013.02.071

9. Bartunek J, Terzic A, Davison BA, et al. Cardiopoietic cell therapy for advanced ischaemic heart failure: results at 39 weeks of the prospective, randomized, double blind, sham-controlled CHART-1 clinical trial. Eur Heart J. 2017; 38: 648-660. doi: 10.1093/eurheartj/ehw543 10. Pavo N, Charwat S, Nyolczas N, et al. Cell therapy for human ischemic heart diseases: Critical review and summary of the clinical experiences. J Mol Cell Cardiol 2014; 75: 12-24. doi: 10.1016/j. yjmcc.2014.06.016

11. Gyöngyösi M, Dib N. Diagnostic and prognostic value of 3D NOGA mapping in ischemic heart disease. Nat Rev Cardiol 2011; 8: 393404. doi: 10.1038/nrcardio. 2011.64

12. Erbs S, Linke A, Adams V, et al. Transplantation of blood-derived progenitor cells after recanalization of chronic coronary artery occlusion: first randomized and placebo-controlled study. Circ Res 2005; 97: 756-62. doi: 10.1161/01.RES.0000185811.71306.8b

13. Assmus B, Honold J, Schächinger V. et al. Transcoronary transplantation of progenitor cells after myocardial infarction. N Engl J Med 2006; 355: 1222-32. doi: 10.1056/NEJMoa051779

14. Assmus B, Fischer-Rasokat U, Honold J, et al. TOPCARE-CHD 
Registry. Transcoronary transplantation of functionally competent $\mathrm{BMCs}$ is associated with a decrease in natriuretic peptide serum levels and improved survival of patients with chronic postinfarction heart failure: results of the TOPCARE-CHD Registry. Circ Res 2007; 100: 1234-41. doi: 10.1161/01.RES.0000264508.47717.6b

15. Diederichsen AC, Moller JE, Thayssen P, et al. Effect of repeated intracoronary injection of bone marrow cells in patients with ischemic heart failure the Danish stem cell study-congestive heart failure truia (DanCell-CHF). Scand Cardiovasc J 2010; 44: 139: 45. doi: 10.1016/j. ejheart.2008.05.010

16. Smits PC, van Geuns RJ, Poldermans D, et al. Catheter-based intramyocardial injection of autologous skeletal myoblasts as a primary treatment of ischemic heart failure: clinical experience with sixmonth follow-up. J Am Coll Cardiol 2003; 42: 2063-9. doi: 10.1016/j. jacc.2003.06.017

17. Perin EC, Dohmann HF, Borojevic R, et al. Transendocardial, autologous bonemarrow cell transplantation for severe, chronic ischemic heart failure. Circulation 2003; 107: 2294-302. doi: 10.1161/01. CIR.0000070596.30552.8B

18. Perin EC, Dohmann HF, Borojevic R, et al. Improved exercise capacity and ischemia 6 and 12 months after transendocardial injection of autologous bone marrow mononuclear cells for ischemic cardiomyopathy. Circulation 2004; 110 (11Suppl. 1): II213-8. doi: 10.1161/01.CIR.0000138398.77550.62

19. Briguori C, Reimers B, Sarais C, et al. Direct intramyocardial percutaneous delivery of autologous bone marrow in patients with refractory myocardial angina. Am Heart J 2006; 151: 674-80.

20. Fuchs S, Kornowski R, Weisz G, et al. Safety and feasibility of transendocardial autologous bone marrow cell transplantation in patients with advanced heart disease. Am J Cardiol 2006; 97: 823-9. doi: 10.1016/j.amjcard.2005.09.132

21. Beeres SL, Bax JJ, Dibbets-Schneider P, et al. Intramyocardial injection of autologous bone marrow mononuclear cells in patients with chronicmyocardial infarction and severe left ventricular dysfunction Am J Cardiol 2007; 100: 1094-8. doi: 10.1016/j.amjcard.2007.04.056 22. Losordo DW, Schatz RA, White CJ, et al. Intramyocardial transplantation of autologous CD34+ stem cells for intractable angina: a phase I/Ila double-blind, randomized controlled trial. Circulation 2007; 115: 3165-72 doi: 10.1161/CIRCULATIONAHA.106.687376

23. Beeres SL, Zeppenfeld K, Bax JJ, et al. Electrophysiological and arrhythmogenic effects of intramyocardial bone marrow cell injection in patients with chronic ischemic heart disease. Heart Rhythm 2007; 4: 257-65. doi: 10.1016/j.hrthm.2006.10.033

24. Beeres SL, Bax JJ, Roes SD, et al. Intramyocardial bone marrow cell transplantation and the progression of coronary atherosclerosis in patients with chronic myocardial ischemia. Acute Card Care 2007; 9 : 243-51. doi: 10.1080/17482940701639385

25. Tse HF, Thambar S, Kwong YL, et al. Prospective randomized tria of direct endomyocardial implantation of bone marrow cells for treat ment of severe coronary artery diseases (PROTECT-CAD trial). Eur Heart J 2007; 28: 2998-3005. doi: 10.1093/eurheartj/ehm485

26. Dib N, Dinsmore J, Lababidi Z, et al. One-year follow-up of feasibility and safety of the first US, randomized, controlled study using 3-dimensional guided catheter-based delivery of autologous skeleta myoblasts for ischemic cardiomyopathy (CAuSMIC study). JACC Cardiovasc Interv 2009; 2: 9-16. doi: 10.1016/j.jcin.2008.11.003

27. van Ramshorst J, Bax JJ, Beeres SL, et al. Intramyocardial bonemarrowcell injection for chronicmyocardial ischemia: a randomized controlled trial. JAMA 2009; 301: 1997-2004. doi: 10.1001/ jama.2009.685.

28. Jiménez-Quevedo P Silva GV, Sanz-Ruiz R, et al. Diabetic and nondiabetic patients respond differently to transendocardial injection of bone marrow mononuclear cells: findings from prospective clinical trials in no-option patients [Spanish]. Rev Esp Cardiol 2008; 61 635-9.

29. Gyöngyösi M, Lang I, Dettke M, et al. Combined delivery approach of bone marrow mononuclear stem cells early and late after myocardial infarction: the MYSTAR prospective, randomized study. Nat Clin Pract Cardiovasc Med 2009; 6: 70-81. doi: 10.1038/ncpcardio1388 30. Pokushalov E, Romanov A, Chernyavsky A, et al. Efficiency of intramyocardial injections of autologous bone marrow mononuclear cells in patients with ischemic heart failure: a randomized study. $\mathrm{J}$ Cardiovasc TransI Res 2013; 3: 160-8. doi: 10.1007/s12265-009-9123-8 31. Heldman AW, Difede DL, Fishman JE, et al. Transendocardial mesenchymal stem cells and mononuclear bone marrow cells for ischemic cardiomyopathy: the TAC-HFT randomized trial. JAMA 2014; 311: 62-73. doi: 10.1001/jama.2013.282909
32. Perin EC, Willerson JT, Pepine CJ, et al. Cardiovascular Cell Therapy Research Network (CCTRN). Effect of transendocardial delivery of autologous bone marrow mononuclear cells on functional capacity, left ventricular function, and perfusion in chronic heart failure: the FOCUS-CCTRN trial. JAMA 2012; 307 (16): 1717-26. doi: 10.1001/ jama.2012.418

33. Guijarro, D, Lebrin, M, Lairez, $O$, et al., Intramyocardial transplantation of mesenchymal stromal cells for chronic myocardia ischemia and impaired left ventricular function: Results of the MESA MI 1 pilot trial, Int J Cardiol, 2016; 209: 258-265. doi: 10.1016/j.ijcard.2016.02.016

34. Perin E, Silva GC, Henry TD, et al. A randomized study of transendocardial injection of autologous bone marrow mononuclear cells and cell function analysis in ischemic heart failure (FOCUS-HF). Am Heart J 2011: 161: 1078-87. doi: 10.1016/j.ahj.2011.01.028

35. Mathiasen AB, Qayyum AA, Jørgensen E, et al. Bone marrow-derived mesenchymal stromal cell treatment in patients with severe ischaemic heart failure: a randomized placebo-controlled trial (MSC-HF trial). Eur Heart J 2015; 36: 1744-53. doi: 10.1093/eurheartj/ehv136 36. Perin EC, Sanz-Ruiz R, Sánchez PL, et al. Adipose-derived regenerative cells in patients with ischemic cardiomyopathy: The PRECISE Trial. Am Heart J. 2014; 168: 88-95. doi: 10.1016/j.ahj.2014.03.022 37. Wojakowski W, Jadczyk T, Michalewska-Włudarczyk A, et al. Effects of Transendocardial Delivery of Bone Marrow-Derived CD133+ Cells on Left Ventricle Perfusion and Function in Patients With Refractory Angina: Final Results of Randomized, Double-Blinded, Placebo-Controlled REGENT-VSEL Trial. Circ Res 2017; 120: 670-680. doi: 10.1161/CIRCRESAHA.116.309009

38. Henry, TD, Pepine, CJ, Lambert, CR, et al. The Athena trials: Autologous adipose-derived regenerative cells for refractory chronic myocardial ischemia with left ventricular dysfunction, Catheter Cardiovasc Interv, 2017; 89: 169-177. doi: 10.1002/ccd.26601

39. Assmus B, Alakmeh S, De Rosa S, et al. Improved outcome with repeated intracoronary injection of bone marrow-derived cells within a registry: rationale for the randomized outcome trial REPEAT. Eur Heart J. 2016; 37: 1659-66. doi: 10.1093/eurheartj/ehv559

40. Assmus B, Walter DH, Seeger FH, et al. Effect of shock wave-facilitated intracoronary cell therapy on LVEF in patients with chronic heart failure: the CELLWAVE randomized clinical trial. JAMA. 2013; 309: 1622-31. doi: 10.1001/jama.2013.3527

41. Kastrup J, Haack-Sørensen M, Juhl M, et al. Cryopreserved Offthe-Shelf Allogeneic Adipose-Derived Stromal Cells for Therapy in Patients with Ischemic Heart Disease and Heart Failure-A Safety Study. Stem Cells Transl Med. 2017; 6: 1963-1971. doi: 10.1002/sctm.170040

42. Fisher SA, Doree C, Mathur A, et al. Stem cell therapy for chronic ischaemic heart disease and congestive heart failure. Cochrane $\mathrm{Da}$ tabase Syst Rev. 2016 Dec 24:12:CD007888. doi: 10.1002/14651858. CD007888.pub2

43. Donndorf P, Kundt G, Kaminski A, et al. Intramyocardial bone marrow stem cell transplantation during coronary artery bypass surgery a meta-analysis. J Thorac Cardiovasc Surg. 2011; 142: 911-20. doi 10.1016/j.jtcvs.2010.12.013

44. Fisher SA, Doree C, Mathur A, et al. Cochrane Corner: stem cell therapy for chronic ischaemic heart disease and congestive heart failure. Heart. 2018; 104: 8-10. doi: 10.1136/heartjnl-2017-311684

45. Gyöngyösi M, Wojakowski W, Lemarchand $P$, et al; ACCRUE Investigators. Meta-Analysis of Cell-based CaRdiac stUdiEs (ACCRUE) in patients with acute myocardial infarction based on individual patient data. Circ Res. 2015; 116: 1346-60. doi: 10.1161/CIRCRESAHA.116.304346

46. Gyöngyösi M, Wojakowski W, Navarese EP, et al. Controversies in meta-analyses results on cardiac cell-based regenerative studies. Circ Res 2016; 118: 1254-1263. doi: 10.1161/CIRCRESAHA.115.307347 47. Gyöngyösi M, Hemetsberger R, Wolbank S, et al. Imaging the Migration of Therapeutically Delivered Cardiac Stem Cells JACC: Cardiovasc Imaging 2010; 3: 772-775. doi: 10.1016/j.jcmg.2010.04.012 48. Thum T, Bauersachs J, Poole-Wilson PA, et al. The dying stem cell hypothesis: immune modulation as a novel mechanism for progenitor cell therapy in cardiac muscle. J Am Coll Cardiol 2005; 46: 1799-802. doi: 10.1016/j.jacc.2005.07.053

49. Greco S, Gorospe M, Martelli F. Noncoding RNA in age-related cardiovascular diseases. Journal of molecular and cellular cardiology 2015; 83: 142-55. doi: 10.1016/j.yjmcc.2015.01.011

50. Devaux Y, Creemers EE, Boon RA, et al. Circular RNAs in heart failure. Eur J Heart Fail 2017; 70: 701-709. doi: 10.1002/ejhf.801 